\title{
Review of IPO Primary Market Pricing Literature
}

\author{
Sabrina Severini ${ }^{1}$ \\ ${ }^{1}$ Department of Management, Università Politecnica delle Marche, Piazzale Martelli, 8, Ancona, Italy \\ Correspondence: Sabrina Severini, Department of Management, Università Politecnica delle Marche, Piazzale \\ Martelli, 8, Ancona, Italy.
}

Received: October 6, 2020

Accepted: November 5, 2020

Online Published: November 16, 2020

doi:10.5430/afr.v9n4p32

URL: https://doi.org/10.5430/afr.v9n4p32

\begin{abstract}
The aim of this paper is to offer a comprehensive review of Initial Public Offering literature on the pricing and interactions that occur in the IPO primary market. Among the multitude of variables that might affect the way shares are priced and sold in new offerings, the role of previous relationships between issuing firms, investment banks, and institutional investors, i.e. key participants in the listing process, is the object of analysis in the present paper. Existing mixed evidence suggests that repeated interactions among the major players could influence the IPO results in two ways: either by reducing asymmetric information problems or by determining opportunistic behaviours which can be seen in well-known secondary market price anomalies. The originality of the paper lies in the fact that it is the first to provide a review of literature on IPO primary market dynamics, thereby highlighting the way in which relationships between key parties of an IPO shape the entire pricing process. Moreover, this study points out the importance of shifting attention to this market in order to better understand IPO pricing dynamics.
\end{abstract}

Keywords: initial public offerings, primary markets, pricing, interactions, due diligence

\section{Introduction}

When a firm is listed on the markets for the first time, an Initial Public Offering (IPO) should be issued at an offer price that is deemed suitable for the firm's shares. This can be problematic as issuers have to cope with typical information asymmetries, as first described by Akerlof (1970) in his "lemons" problem. Given that it is often not possible to discern between high- and low-quality firms, the market could fail as the low-quality firms prevail over the high-quality ones (Varshney \& Robinson, 2004). Nonetheless, the quality of issuing firms cannot easily be predicted because listing firms are often young and new to the market, and the information environment, from which investment decisions can be made, is limited; indeed, there are no secondary market performance records and the operating history data is short (Thornton, Adams \& Hall, 2009). All these factors increase the valuation uncertainty of IPOs and could give rise to so-called secondary market pricing anomalies, such as underpricing, hot issue markets, and long run underperformance (Ibbotson, Sindelar \& Ritter, 1988; Ivanov, 2018; Jenkinson \& Ljungqvist, 2001; Morton, 1998; Ritter \& Welch, 2002). Several studies have attempted to explain the origin of these anomalies, mainly focusing on the dynamics that occur when trading begins but often leading to conflicting evidence. Indeed, these puzzling phenomena raise questions concerning market efficiency, but they also suggest that "the solution to the underpricing puzzle has to lie in focusing on the setting of the offer price" (Ritter \& Welch, 2002 p.12). Hence, the origin of these anomalies can also be ascribed to the way in which the offer price is fixed in the primary market. However, only a few studies have delved into this aspect, especially in the US context (Note 1), partly because available primary market data is scarce.

Thus, the first contribution of this study consists in a review of literature that is mainly focused on IPO primary market dynamics. Put differently, this paper contributes to the existing literature by portraying a broader picture of the dynamics that influence the IPO pricing decision in the primary market.

The way offer prices are defined in the primary market is affected by the informational scenario: on the one hand IPO firms, vis-à-vis possible investors, may attempt to misrepresent themselves, and, on the other hand, investors are potentially underinformed about outside factors (Benveniste \& Spindt, 1989). Neither the issuers nor their underwriters (Note 2) have exact knowledge of how the market will valuate the shares, thus making it extremely difficult to overcome this informational friction. On the contrary, the certification role of underwriters may help issuers to deal with the first type of informational asymmetry (Booth \& Smith, 1986; Smith, 1986). Given that firms' information opacity creates high uncertainty with respect to share value, intermediaries have the potential to 
overcome some problems associated with underwriting. Issuers looking for capital know their business opportunities better than investors, and the latter know more about the conditions under which they are able to finance the firm. Each party has an incentive to protect its informational advantage. Consequently, the IPO market is one in which 'structural holes' in the flow of information require the mediation of a broker (Burt, 2009). These brokers, or third parties, help disparate actors to interact, to exchange information, and to conclude transactions. In the IPO context, the agents that typically play this role are investment bankers; through repeated dealings with large networks of issuers and investors, they build trust among them, screening out information that is not readily disclosed between counterparts. In this sense, investment banks can be seen as "coordinators of largescale, strategic information networks" (Wilhelm, 2005, p.4). However, it should be noted that the information advantage that an investment bank acquires through repeated dealings might not always be used in the best interest of the issuer. As a matter of the fact, it has been argued that reasons for the above-mentioned pricing anomalies might lie with how underwriters set the offering price and oversee allocations in the primary market.

Although all players involved in the IPO (i.e., investment banks, firms, institutional investors, venture capitalists and analysts, lawyers, accountants, and government regulators) play an important role in pricing new securities, the firm, the lead underwriter and its syndicate, and institutional investors are the most prominent; their role is greater in establishing the offering price and thus, in shaping early market performance (Pollock, 2004). However, these players may be driven by different and not necessarily compatible motivations. The firm's incentives are to maximize wealth for the original shareholders, to raise capital, and to dilute capital; the investment banker's bottom-line incentive is to profit from the deal; lastly, investors are motivated by the prospect of a good return on their investment. Although established relationships and repeated interaction between the key parties of this market are able to reduce uncertainty regarding the firm's value, opportunistic behaviors could also be involved in this process. Thus, the second contribution of the present paper consists in highlighting the way in which primary market relationships established between the issuing firm, the investment bank, and institutional investors influence the entire price setting process. More specifically, this study offers a broader picture, building on the work of previous studies, of the importance of relationships and their impact on pricing, in each phase of the primary market.

The remainder of this paper is organized as follows: the IPO pricing process is described in Section 2, while an overview of how the underwriter is chosen and the underwriting syndicate is formed is provided in Section 3. The key aspects of the due diligence process are presened in Section 4 and the role played by intermediaries and institutional investors during the waiting period, or bookbuilding phase, are discussed in Section 5. Concluding remarks are offered in Section 6.

\section{The IPO Pricing Process}

In order to fully investigate IPO pricing in the primary market and to highlight the role of bookbuilding in the pricing process, a better understanding of each step of the IPO is needed. In the U.S., the offering process typically consists of three important steps: selecting the underwriter leading the listing process, registering with the Securities and Exchange Commission (SEC), and deciding the final offer price on the day before the offer. As shown in Figure 1, the IPO usually starts with engaging an underwriter that will be the lead manager. The underwriter is designated to evaluate the firm, to form an underwriters' syndicate and to fill in the preliminary prospectus or file an amended statement with the Securities and Exchange Commission (SEC). The same investment bank also conducts a due diligence investigation and assists the firm in pricing and marketing the new stocks (Ibbotson \& Ritter, 1995). Given the multitude of activities that underwriters are requested to carry out in an IPO, it is possible that they share some of those activities with other figures such as a global coordinator, co-lead managers, and bookrunners but, in most of the cases, the tasks are carried out by a single underwriter. Therefore, at the beginning of the offering process, with the selection of an underwriter the underwriting syndicate is also set up. After the issuer has chosen the underwriter, due diligence begins, and the preliminary prospectus is made available to potential investors. In this document, the first price indication is disclosed in the form of an offer price range. It represents the minimum and the maximum achievable offer price, corresponding to the lowest acceptable price for the issuing firm and the highest price predicted by the underwriter to clear the market (Thompson, 2016). Indeed, during the bookbuilding phase, the lead underwriter meets regular investors, namely those that are actively involved in purchasing shares of newly issued stocks, during the road shows. Those meetings are important for both underwriters and issuing firms, because they acquire nonbinding indications of interest, helpful in estimating the demand and the offer curves and, consequently, to "build the book" (Ritter \& Welch, 2002). Up to this point, and through the registration period, the price may be adjusted upward or downward relative to the midpoint of the range (Note 3) in response to investors' demand (Ibbotson et al., 1988). Then, on the day before the offering the offer price is finally set. 
An additional key point of primary market pricing regards the time when the above-mentioned information is produced and/or revealed (Lowry, Michaely \& Volkova 2017). Consistent with Hanley and Hoberg (2010), information production occurs prior to the IPO, during the due diligence phase in talks with management, suppliers, venture capitalists etc. In keeping with this view, the initial price range already contains valuable information regarding the firm's intrinsic value (Aussenegg, Pichler \& Stomper, 2006; Chang, Chiang, Qian \& Ritter, 2016; Derrien \& Kecskes, 2007). By contrast, another stream of literature sustains that underwriters may get valuable information about demand from the repeated nature of interactions with regular investors, during the bookbuilding process (Benveniste \& Spindt, 1989; Chiang, Qian \& Sherman, 2010). In this case, the revision of the offer price during the registration period is useful for forecasting investor demand. In line with Crain, Parrino and Srinivasan (2017), due diligence activities and bookbuilding are not independent but complementary; information production begins with the due diligence, continues through the bookbuilding, and characterizes the entire primary market.

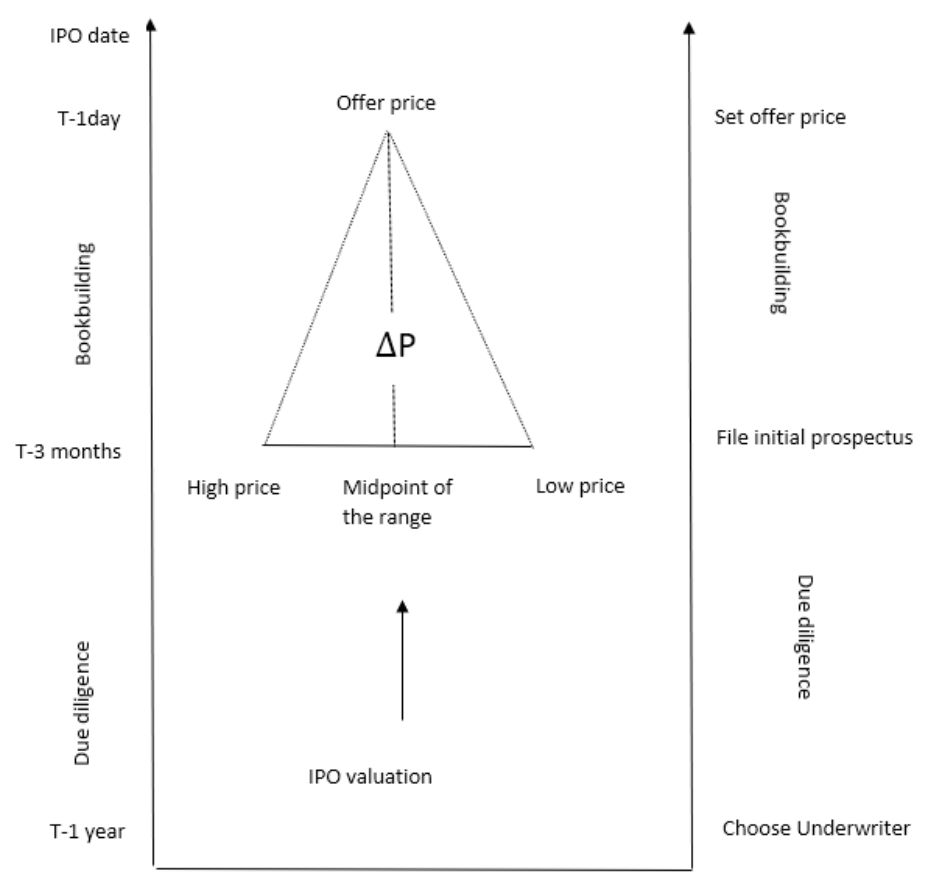

Figure 9. IPO primary market pricing process

This figure shows the IPO primary market process. After the issuing firm chooses an underwriter, usually one year before the IPO, the due diligence valuation begins, and the initial prospectus is filed. As outlined above, preliminary information regarding the offering to come is provided to the public as a price range from high to low, with the expected offer price in the midpoint of this range. During the waiting period the price can be revised according to the signals received from institutional investors, up until the day before the offering when the final offer price is set. $\mathrm{T}$ is the IPO date.

\section{Choice of Underwriter and Syndicate Formation}

The extant literature recognizes that various factors can influence the selection of the underwriter; these include the investment bank's reputation and certification role (Corwin \& Schultz, 2005), the underwriter's distribution channel and the networking function accumulated by means of repeated dealings in securities offerings, brokerage activities, and analyst research coverage (Dunbar, 2000; Huang, Shangguanand \& Zhang, 2008; Krigman, Shaw \& Womack, 1999; Michaely \& Womack, 1999). In addition, other services provided after the listing, such as price support and market making operations, might impact on the underwriter selection. However, it is worthy of note that pre-existing bank relationships appear to be the main factor influencing that choice (Bharath, Dahiya, Saunders \& Srinivasan 2007; Klein \& Zoeller, 2001). Several scholars have pointed out the benefits to firms that have lending relationships (Petersen \& Rajan, 1994; 1995; James, 1987; Diamond, 1984; 1991; Stiglitz \& Weiss, 1983). In fact, these authors suggest that firms that have recurrent relationships with financial institutions have fewer credit constraints, given that banks collect relevant information through their lending and monitoring activities and are able to assess the firm's 
value more accurately (Petersen \& Rajan, 1994; 1995). Since the market and the issuers are asymmetrically informed regarding the firm's true value, the latter must provide information on its outcomes and future prospects so as to receive feedback from possible investors (Benveniste, Busaba \& Wilhelm, 2002). Nevertheless, disclosing information regarding the firm's business exposes it to the potential risk and, consequently, the cost of revealing proprietary information to rivals. In this context, having a consolidated relationship over time with the underwriter that manages the IPO might contribute to the certification of the issuer's value and facilitate the listing process. An inside bank has an informational advantage that can mitigate asymmetric information problems and might help to price the firm's new issue more accurately. However, the information advantage held by the underwriter could also give rise to a conflict of interest. These issues relative to relationship banking have received much attention after the 1999 Gramm-Leach-Bliley Act, which repealed the Glass-Steagall Act in the United States and introduced a universal banking system. Empirical evidence supports the certification role of underwriters in the IPO context. In fact, Bharath et al. (2007) and Schedone (2004) suggest that relationship banking reduces the cost of going public thanks to fewer asymmetric information problems. Schedone (2004) reports that firms with lending ties to a potential underwriter face a $16 \%$ lower cost of equity capital compared to that of firms with no banking relationships. Ang and Richardson (1994), Kroszner and Rajan (1994), Puri (1999) and Benzoni and Schedone (2010) show that equity issues underwritten by relationship banks have a better long run performance compared to IPOs underwritten by investment houses. In sum, previous findings reveal that, with greater information on issuing firms, universal banks might use that knowledge to float stocks of the "cherries", and stay away from the "lemons" (Ber, Yafeh \& Yosha, 2001).

Another stream of literature suggests that having past relationships with other banks and institutional investors is crucial for being included in the underwriting syndicate. As suggested in James (1992), banks are likely to increase their reputation and their network of relationships, through repeated dealings. Cooney, Madureira, Singh and Yang (2015) find that when interpersonal social ties are forged with the issuing firm, the bank is more likely to participate in the underwriting syndicate. These social relationships generate better outcomes for both issuers and investment banks; the former obtains gains for its pre-IPO shareholders and greater information production while the latter is likely to receive a greater reward, a more prominent role in the IPO, and greater share allocations. Investment banks are also included in the IPO underwriting syndicate because of their inclusion in other syndicates led by the same book manager (Corwin \& Schultz, 2005). Underwriters' relationships can foster familiarity, help mitigate moral hazard problems, and lower search costs. Thus, underwriters might relay information directly from co-managers and indirectly through talks with the IPO firm; this double channel of information might affect the probability and amplitude of offer price revisions. The effect is more evident when there are multiple lead underwriters (MLUs); in fact, between 2001 and 2010, approximately half of the IPOs were managed by underwriting syndicates with multiple bookrunners (Corwin \& Schultz, 2005). A crucial benefit of MLU syndicates is that they may produce more information than a single underwriter can (Barzel, Habib, \& Johnsen, 2000; Pichler \& Wilhelm, 2001). The structure of investment bank peer networks has also been studied in terms of what the quantity and quality of information and resources that flow through the networks imply (Chuluun, 2015; Bajo, Chemmanur, Simonyan \& Tehranian, 2016; Rumokoy, Neupane \& Chung, 2019). Making use of social network analysis, these studies suggest that peer relationships represent important channels of information and resources. An underwriter might indirectly take advantage of other banks' networks of clients and investors to gain more information and increase its distribution channels. In particular, Chuluun (2015) finds that there is a higher correlation between frequent, greater offer price revisions and IPOs underwritten by lead managers with more central and cohesive networks. Bajo et al. (2016) suggest that investment banking networks make it possible to not only attract the attention of institutions but also to extract price-relevant information about the issuing firm from institutional investors. The positive effect of network centrality in terms of IPO outcomes has also been examined in the Chinese market by Rumokoy et al. (2019). As a matter of the fact, investment banking is a sector that is based more on relationships than on transactions. Although peer relationships between banks and institutional investors help to build trust, with a view to gaining price-relevant information, the investor network has not been explicitly analyzed. One main limitation to the empirical examination of underwriters-institutional investor networks is that underwriters are not required to publicize their order book and allocation schedule.

\section{The Due Diligence Process}

The underwriter performs an initial due diligence investigation of the firm in order to file the S-1 registration form with the SEC. In the U.S., the Securities and Exchange Commission regulations provide guidelines regarding the price range that must be included in the preliminary prospectus, as well as the total of shares, and their aggregate value, that are being registered. Item 501(b)(3) of SEC Regulation S-K states that the price range must reflect a 
"bona fide estimate" of the final offering price; however, there is room for interpretation as to what is meant by this, specifically (Note 4). Indeed, a price range is deemed a bona fide estimate and revised and/or approved at the discretion of the SEC. Generally speaking, where there is higher uncertainty regarding the value of IPO shares to be issued underwriters tend to set a broader filing range (Bajo et al., 2016). This uncertainty could be the result of difficulties in estimating a firm's value when it is new to the market with a short operating history and no trading performance that can be used for forecasting; however, lack of certainty could also ensue because the lead manager will choose the initial IPO offer price range based on the expected value of institutional investor demand. Nevertheless, the value of regular investors' demand it is not officially known when the initial price range is set; it is revealed only later, during the bookbuilding process (Hanley, 1993; Ljungqvist \& Wilhelm, 2002; Wang \& Yung, 2011; Chuluun, 2015). Given the scarcity of clear information, underwriters could assess issuing firms using markers, such as retail investor attention (Colaco, De Cesari \& Hegde, 2017), for example. Incorporating different variables to evaluate market conditions and investor demand for an IPO (McCarthy, 1999) might result in a more accurate valuation for newly established firms and reduce the need for underwriters to undertake costly price stabilization activities when trading starts (Chowdhry \& Nanda, 1996). Understanding and predicting how the market will respond to the issue helps to reduce the uncertainty that remains even after the investigation of the issuer (in the due diligence phase) and after the underwriters' surveys of the regular investors (during the waiting period). An examination of US IPOs between 2004 and 2011 by Colaco et al. (2017) revealed that an increase in retail attention, proxied by Google's search volume index (SVI) in the month before the IPO, was associated with higher initial valuations. Moreover, Da, Enggelberg and Gao (2011) showed that the SVI contributed to the large underpricing and long-run underperformance for a sample of IPOs from 2004 to 2008. However, "no formal theoretical model has been presented in the existing literature regarding the process by which underwriters choose the initial offer price range" (Chemmanur, Krishnan \& Yu 2016, p.15). It is reasonable to think that the existence of repeated interactions between the lead manager and the underwriter syndicate or regular investors could influence the IPO price range setting. The lead underwriter might rely on its investment banking network, indirectly, and its clientele network of regular investors, directly, to obtain information from institutions regarding their interest in the issuing firms. In other words, underwriters might be able to glean more accurate information even before the bookbuilding begins, during the due diligence step, from their previous interactions with regular investors. Such advantages could determine more precise initial price ranges because the lead manager would be dealing with less uncertainty regarding regular investors' demand. Although peer relationships between banks and institutional investors help investment banks to win the trust of investors, thus making the market more optimistic, the impact of investor networks on IPO price range setting has not been explicitly examined.

\section{The Bookbuilding Phase}

Once the company has met the registration and disclosure requirements of the SEC, the marketing road show begins; during this phase the IPO is promoted by both the issuing firm and the investment bank. Institutional investors show their interest, to the underwriter(s), by submitting non-binding bids which are used to proxy the demand curve and used as a gauge to establish the offer price. If the underwriter works well at marketing the IPO, market demand can be better understood and, indeed, boosted. Should the pre-offering demand be too high or, conversely, too low, the underwriter can broaden or narrow the price range in an amended filing. Setting the final offer price represents a challenge for the bank, which must preserve its professional reputation but, at the same time balance contrasting interests; therefore, the final offer price should neither be set too high for issuers nor too low for investor-buyers. A great deal rides on setting the right offer price: too high and undersubscribed securities could leave the underwriter with unsold shares and the IPO firm with less capital, too low and the money left on the table signifies a loss of future business for the underwriter. Hence, if there is a high demand during the road show, the best strategy for underwriters is to only moderately adjust the offer price upwards; this means that, quite often, rather than increasing the final offer price to match the fair market value, investment banks are conservative in their price adjustment. Studies dating back to Logue (1973) suggest that during the bookbuilding phase a plausible explanation for underpricing lies in the degree of revision of the offer price from the midpoint of the original range (Ritter, 2011). Thus, if in response to investors' demand the price withstands an upward revision, there is, on average, a more marked underpricing than in IPOs that are revised downward (Hanley, 1993). In other terms, in case of high demand during the waiting period, the offering price is adjusted upward, but the adjustment could be incomplete (Ibbotson et al., 1988), meaning that the information obtained in the bookbuilding is only partially reflected in the revised offer price. This phenomenon, known as partial adjustment, was first documented by Hanley (1993). The resulting underpricing compensates institutional investors for their transparency is sharing private information (Cornelli \& Goldreich, 2001). The kind of information that is usually incorporated into offer prices has been the subject of 
analysis in a variety of studies; for the sake of price efficiency, in order for private information to be revealed and incorporated, there needs to be an incentive (Hanley, 1993; Cornelli \& Goldreich, 2001; Benveniste \& Spindt, 1989), while publicly available information should automatically be taken into account when the final offer price is set. As pointed out in Lowry and Schwert (2004), Bradley and Jordan (2002) and Derrien (2005), IPO offer prices tend to under-adjust to public information because the underpricing can be forecast using available information before the listing day. However, Lowry and Schwert (2004) conclude that the way underwriters treat public information is nearly in line with an efficient IPO pricing process.

The increased use of bookbuilding from the 90s onward, has given rise to a debate regarding the advantages associated with this mechanism for selling IPOs because, unlike auctions, bookbuilding allows underwriters to obtain information from institutional investors, thus increasing price discovery (Benveniste \& Busaba, 1997) and giving them control over both price and allocation (Lowry et al., 2017). Moreover, bookbuilding reduces the risk of undersubscription (Sherman, 2005) and consequently, helps to increase the expected proceeds. Sherman (2005) argues that the opportunity to build an underwriter's network of regular investors greatly contributes to the growing popularity of bookbuilding as an IPO allocation mechanism. In other terms, while the costs associated with bookbuilding are higher, it is the most predominantly used method because banks can develop a reputation for fair dealing by interacting repeatedly with the network of regular investors. Although one of the peculiarities of bookbuilding is that underwriters can determine at which price a firm goes public and controls the allocation of its shares, these advantages must be weighed against the possible conflicts of interest that could arise from allowing underwriters to make preferential allocations (Lowry et al., 2017).

Indeed, two streams of literature discuss the role played by underwriter-institutional investor relationships during bookbuilding. In the first stream, some studies suggest that the allocation discretion of the underwriters significantly improves the efficiency of IPO prices by inducing optimal information production. Others sustain that the combination of underwriters' discretion in the allocation of shares and the relationship between underwriters and institutional investors entails opportunistic behavior that allows underwriters to obtain private benefits. More specifically, the open question is whether the 'discretionary' share allocation policy of the lead managers and their repeated interactions with regular investors or the 'discriminatory' practice that serves the bankers' interests at the expense of other parties to the transaction (Ljungqvist \& Wilhelm, 2002) is beneficial for the issuer. Consistent with bookbuilding theories, when investment banks sell repeatedly to the same investors, they collect valuable and reliable information in the premarket, which is used to more accurately price the IPO; accordingly, underpricing is reduced in exchange for priority in future IPO allocations (Benveniste \& Spindt, 1989; Benveniste \& Wilhelm, 1990; Spatt \& Srivastava, 1991; Sherman \& Titman, 2002). Several papers provide support for the prediction that investors who provide the greatest amount of information bid aggressively, thus obtaining the largest allocations (Note 5) (Cornelli \& Goldreich, 2001, 2003; Jenkinson \& Jones, 2004, 2009; Aggarwal, Krigman \& Womack 2002; Chemmanur, Hu \& Huang, 2010).

According to the second steam of literature, favoritism in the allocation is not directly used in the best interests of the IPO firm; consequently, more money is left on the table (Ritter \& Welch, 2002). In the agency-based view (Baron, 1982), the underwriter's discretion will aggravate the problem between the underwriter and company issuing the IPO (Ljungqvist \& Wilhelm, 2002). In this event, underpriced shares are given to institutional investors that can provide some form of kickback. It has been amply documented (Reuter, 2006; Nimalendran et al., 2007; Goldstein et al,2011; Ritter \& Zhang, 2007) that underwriters favor rent-seeking investors who pay back part of their trading profits in so-called soft dollars; these consist of commissions that are higher than the direct execution costs. Moreover, other studies such as Hao (2007), Edwards and Hanley (2010), and Griffin et al. (2007) report the use of laddering, where shares are allocated under the condition that the investor will buy additional quantities in the immediate aftermarket.

\section{Conclusion}

The IPO literature is rich and vast and, for most of the part, focused on secondary market pricing anomalies (underpricing, hot issue markets, and long-run underperformance). Advocates of financial market efficiency find the empirical evidence on IPO pricing mechanisms to be something of a conundrum. The main difficulty associated with an initial public offering is to assess the value of the issuing firm and, subsequently, set an accordingly commensurate offer price. Indeed, the high uncertainty surrounding the actual value of the IPO makes investing in these shares both risky and volatile; as a consequence, IPO initial return distributions often appear positively skewed with heavy tails (Lowry, Officer \& Schwert, 2010; Guo, 2017). The pricing decision and the valuation of the firm's potentialities typically occur in the primary market. Despite the relevance of the IPO primary market - where new securities are created and priced and where secondary market pricing anomalies might originate - it has received 
relatively little attention. To address this gap, the primary aim of this paper is to shed some light on the importance of the role played by the dynamics that occur in the primary market. Indeed, setting the price of an initial public offering is fundamental for a successful listing, but it is also difficult because the firm is informatively opaque to potential investors. More generally, the IPO market is a mediated market characterized by a high incidence of asymmetric information. In this context, a situation of potential conflict of interest can arise from any of the different market operators because it is highly probable that one or more of the agents has ties to a different principal (Arthurs, Hoskisson, \& Busenitz 2008). Each of the main players involved in an IPO - issuers, investment banks, and institutional investors - has different incentives that are not always compatible. Within an IPO deal network the lead underwriter occupies a key position: this player engages with institutional investors and other banks to encourage them to take part in the offer and also helps disconnected actors - namely investors and issuing firms - to interact, exchange information, and conclude transactions. The role played by relationships and repeated interaction among the key parties of this market is crucial for mitigating the uncertainty about the value of the company; nevertheless, opportunistic behavior, that allows underwriters to obtain private benefits from omitting relevant information, could also be a factor (Miller, 2018).

In sum, the contribution brought by the present study is novel in that it not only reviews the IPO primary market pricing process but also underscores how relationships between three major parties involved in an IPO transaction shape the early market performance; this work thereby offers a different perspective of analysis compared to the extant literature. Moreover, by focusing on a relatively little-explored aspect, this study could offer insights for future research.

The review provided in this paper shows that although the IPO primary market has received relatively little attention due to the lack of transparency in bidding and allocation data, the dynamics that take place in this market are able to influence the outcome of an IPO. Existing mixed evidence spotlights the importance of shifting attention more squarely on the primary market in order to better understand pricing dynamics. Clearly, the influence that repeated interactions have on the final offer price decision is an aspect that has been infrequently analysed. Nevertheless, this area of IPO research represents one of the most promising future avenues. Market participants and regulators might encourage the disclosure of bidding and allocation data relative to primary market information (Ibbotson \& Ritter, 1995 ) which would go a long way in helping academics and regulators alike to gain a better understanding of this and related topics.

\section{References}

Aggarwal, R. K., Krigman, L., \& Womack, K. L. (2002). Strategic IPO underpricing, information momentum, and lockup expiration selling. Journal of financial economics, Vol. 66 No. 1, pp.105-137. https://doi.org/10.1016/S0304-405X(02)00152-6

Akerlof, G. A. (1970). The market for" lemons": Quality uncertainty and the market mechanism. The quarterly journal of economics, Vol. 84, No. 3, pp.488-500. https://doi.org/10.2307/1879431

Ang, J. S., \& Richardson, T. (1994). The underwriting experience of commercial bank affiliates prior to the Glass-Steagall Act: A reexamination of evidence for passage of the act. Journal of Banking and Finance, Vol. 18 No. 2, pp.351-395. https://doi.org/10.1016/0378-4266(94)00039-5

Arthurs, J. D., Hoskisson, R. E., Busenitz, L. W., \& Johnson, R. A. (2008). Managerial agents watching other agents: Multiple agency conflicts regarding underpricing in IPO firms. Academy of Management Journal, Vol. 51 No. 2, pp.277-294. https://doi.org/10.2307/20159509

Aussenegg, W., Pichler, P., \& Stomper, A. (2006). IPO Pricing with Bookbuilding and a When- Issued Market. Journal of Financial and Quantitative Analysis, Vol. 41 No. 4, pp.829-862. https://doi.org/10.1017/S0022109000002660

Bajo, E., Chemmanur, T. J., Simonyan, K., \& Tehranian, H. (2016). Underwriter networks, investor attention, and initial public offerings. Journal of Financial Economics, Vol. 122 No. 2, pp.376-408. https://doi.org/10.1016/j.jfineco.2015.12.001

Baron, D. P. (1982). A model of the demand for investment banking advising and distribution services for new issues. The Journal of Finance, Vol. 37 No. 4, pp.955-976. https://doi.org/10.2307/2327760

Barzel, Y., Habib, M. A., \& Johnsen, D. B. (2000). Ipo syndicates, private foreknowledge, and the economics of excess search. George Mason Law Economics Research paper, (00-29), Virginia. http://dx.doi.org/10.2139/ssrn.232242 
Beatty, R. P., \& Ritter, J. R. (1986). Investment banking, reputation, and the underpricing of initial public offerings. Journal of financial economics, Vol. 15 No. 1 pp.213-232. https://doi.org/10.1016/0304-405X(86)90055-3

Benninga, S., Helmantel, M., \& Sarig, O. (2005). The timing of initial public offerings. Journal of Financial Economics, Vol. 75 No. 1, pp.115-132. https://doi.org/(...).jfineco.2003.04.002

Benveniste, L. M. \& Busaba, W. Y. (1997). Bookbuilding vs. fixed price: An analysis of competing strategies for marketing IPOs. Journal of Financial and Quantitative Analysis, Vol. 32 No. 4, pp.383-403. https://doi.org/10.2307/2331230

Benveniste, L. M., \& Spindt, P. A. (1989). How investment bankers determine the offer price and allocation of new issues. Journal of Financial Economics, Vol. $24 \quad$ No. 2, pp.343-361. https://doi.org/10.1016/0304-405X(89)90051-2

Benveniste, L. M., \& Wilhelm, W. J. (1990). A comparative analysis of IPO proceeds under alternative regulatory environments. Journal of financial economics, $28(1-2), \quad$ 173-207. https://doi.org/10.1016/0304-405X(90)90052-2

Benveniste, L. M., Busaba, W. Y., \& Wilhelm Jr, W. J. (2002). Information externalities and the role of underwriters in primary equity markets. Journal of Financial Intermediation, Vol. 11 No. 1, pp.61-86. https://doi.org/10.1006/jfin.2000.0310

Benzoni, L., \& Schenone, C. (2010). Conflict of interest and certification in the us IPO market. Journal of Financial Intermediation, Vol. 19 No. 2, pp.235-254. https://doi.org/10.1016/j.jfi.2009.02.003

Ber, H., Yafeh, Y., \& Yosha, O. (2001). Conflict of interest in universal banking: Bank lending, stock underwriting, and fund management. Journal of Monetary Economics, Vol. 47 No. 1, pp.189-218. https://doi.org/10.1016/S0304-3932(00)00051-9

Bharath, S., Dahiya, S., Saunders, A., \& Srinivasan, A. (2007). So what do I get? the bank's view of lending relationships. Journal of financial Economics, Vol. 84 No.2, pp.368-419. https://doi.org/10.1016/j.jfineco.2005.08.003

Booth, J. R., \& Smith II, R. L. (1986). Capital raising, underwriting and the certification hypothesis. Journal of Financial Economics, Vol. 15 No.1, pp.261-281. https://doi.org/10.1016/0304-405X(86)90057-7

Bradley, D. J., \& Jordan, B. D. (2002). Partial adjustment to public information and IPO underpricing. Journal of Financial and Quantitative Analysis, Vol. 37 No. 4, pp.595-616. https://doi.org/10.2307/3595013

Burt, R. S. (2009). Structural holes: The social structure of competition. Harvard university press.

Chang, C., Chiang, Y. M., Qian, Y., \& Ritter, J. R. (2017). Pre-Market Trading and IPO Pricing. Review of Financial Studies, Vol. 30 No. 3, pp.835-865 https://doi.org/10.1093/rfs/hhw032

Chemmanur, T. J., Hu, G., \& Huang, J. (2010). The role of institutional investors in initial public offerings. The Review of Financial Studies, Vol. 23 No. 12, pp.4496-4540. https://doi.org/10.1093/rfs/hhq109

Chemmanur, T. J., Krishnan, K., \& Yu, Q. (2016). Venture Capital Backing, Investor Attention, and Initial Public Offerings. Working paper https://doi.org/10.2139/ssrn.2851196

Chen, H.-C., \& Ritter, J. R. (2000). The seven percent solution. The Journal of Finance, Vol. 55 No. 3, pp.1105-1131. https://doi.org/10.1111/0022-1082.00242

Chiang, Y. M., Qian, Y., \& Sherman, A. E. (2010). Endogenous Entry and Partial Adjustment in IPO Auctions: Are Institutional Investors Better Informed? Review of Financial Studies, Vol. 23 No.3, pp.1200-1230. https://doi.org/10.1093/rfs/hhp066

Chowdhry, B., \& Nanda, V. (1996). Stabilization, syndication, and pricing of IPOs. Journal of Financial and Quantitative Analysis, Vol. 31 No. 1, pp.25-42. https://doi.org/10.2307/2331385

Chuluun, T. (2015). The role of underwriter peer networks in IPOs. Journal of Banking \& Finance, Vol. 51, pp.62-78. https://doi.org/10.1016/j.jbankfin.2014.11.001

Colaco, H. M., De Cesari, A., \& Hegde, S. P. (2017). Retail investor attention and IPO valuation. European Financial Management, Vol. 23 No. 4, pp.691-727. https://doi.org/10.1111/eufm.12113

Cooney, J. W., Madureira, L., Singh, A. K., \& Yang, K. (2015). Social ties and IPO outcomes. Journal of Corporate Finance, Vol. 33, pp.129-146. https://doi.org/10.1016/j.jcorpfin.2015.05.003 
Cornelli, F., \& Goldreich, D. (2001). Bookbuilding and strategic allocation. The Journal of Finance, Vol. 56 No. 6 , pp.2337-2369. https://doi.org/10.1111/0022-1082.00407

Cornelli, F., \& Goldreich, D. (2003). Bookbuilding: How informative is the order book? The Journal of Finance, Vol. 58 No. 4, pp.1415-1443. https://doi.org/10.1111/1540-6261.00572

Corwin, S. A., \& Schultz, P. (2005). The role of IPO underwriting syndicates: Pricing, information production, and underwriter competition. The Journal of Finance, Vol. 60 No.1, pp.443-486. https://doi.org/10.1111/j.1540-6261.2005.00735.x

Crain, N., Parrino, R., \& Srinivasan, R. (2017). Uncertainty, prospectus content, and the pricing of initial public offerings. Working Paper. http://dx.doi.org/10.2139/ssrn.3082429

Da, Z., Enggelberg, J., \& Gao, P. (2011). In search of attention. The Journal of Finance, Vol. 66 No.5, pp.1461-1499. https://doi.org/10.1111/j.1540-6261.2011.01679.x

Derrien, F. (2005). Ipo pricing in "hot" market conditions: Who leaves money on the table? The Journal of Finance, Vol. 60 No. 1, pp.487-521. https://doi.org/10.1111/j.1540-6261.2005.00736.x

Derrien, F., \& Kecskes, A. (2007). The Initial Public Offerings of Listed Firms. The Journal of Finance, 62(1), 447-479. https://doi.org/10.1111/j.1540-6261.2007.01212.x

Diamond, D. W. (1984). Financial intermediation and delegated monitoring. The review of economic studies, Vol. 51 No. 3, pp.393-414. https://doi.org/10.2307/2297430

Diamond, D. W. (1991). Monitoring and reputation: The choice between bank loans and directly placed debt. Journal of political Economy, Vol. 99 No. 4, pp.689-721. https://dx.doi.org/10.1086/261775

Dunbar, C. G. (2000). Factors affecting investment bank initial public offering market share. Journal of Financial Economics, Vol. 55 No.1, pp.3-41. https://doi.org/10.1016/S0304-405X(99)00043-4

Edwards, A. K., \& Hanley, K. W. (2010). Short Selling in Initial Public Offerings. Journal of Financial Economics, Vol. 98 No.1, pp.21-39. https://doi.org/10.1016/j.jfineco.2010.03.010

Field, L. C., \& Lowry, M. (2009). Institutional versus individual investment in IPOs: The importance of firm fundamentals. Journal of Financial and Quantitative Analysis, Vol. 44 No. 3, pp. 489-516. https://doi.org/10.1017/S0022109009990032

Goldstein, M. A., Irvine, P., \& Puckett, A. (2011). Purchasing IPOs with commissions. Journal of Financial and Quantitative Analysis, Vol. 46 No. 5, pp.1193-1225. https://doi.org/10.1017/S0022109011000317

Goyal, V. \& Tam, H. K. (2013). Investor characteristics, relationships, and IPO allocations. Working Paper.

Griffin, J. M., Harris, J. H., \& Topaloglu, S. (2007). Why are IPO Investors Net Buyers through Lead Underwriters? Journal of Financial Economics, Vol. 85 No. 2, pp.518-551. https://doi.org/10.1016/j.jfineco.2005.12.005

Guo, Z. (2017) "Heavy tailed Distributions and Risk Management of Equity Market Tail Events," Journal of Risk \& Control, 2017, vol. 4, No. 1, pp.31-41.

Hanley, K. W. (1993). The underpricing of initial public offerings and the partial adjustment phenomenon. Journal of financial economics, Vol. 34 No.2, pp.231-250. https://doi.org/10.1016/0304-405X(93)90019-8

Hanley, K. W. (2017). The economics of primary markets. Working Paper. https://doi.org/10.2139/ssrn.3046256

Hanley, K. W. and Hoberg, G. (2010). The information content of IPO prospectuses. The Review of Financial Studies, Vol.23 No.7, pp.2821-2864. https://doi.org/10.1093/rfs/hhq024

Hao, Q. (2007). Laddering in Initial Public Offerings. Journal of Financial Economics, Vol. 85 No.1, pp.102-122. https://doi.org/10.1016/j.jfineco.2006.05.008

Huang, R., Shangguan, Z., \& Zhang, D. (2008). The networking function of investment banks: Evidence from private investments in public equity. Journal of Corporate Finance, Vol. 14 No.5, pp.738-752. https://doi.org/10.1016/j.jcorpfin.2008.09.014

Ibbotson, R. G., \& Ritter, J. R. (1995). Initial public offerings. Handbooks in operations research and management science, pp.993-1016. https://doi.org/10.1016/S0927-0507(05)80074-X

Ibbotson, R. G., Sindelar, J. L., \& Ritter, J. R. (1988). Initial public offerings. Journal of Applied Corporate Finance, Vol. 1 No.2, pp.37-45. http://dx.doi.org/10.1111/j.1745-6622.1988.tb00164.x 
Ivanov, S. I. (2018). The performance of IPOs excluding the jump. Studies in Economics and Finance, Vol. 35 No.2, pp.273-286. https://doi.org/10.1108/SEF-11-2016-0264

James, C. (1987). Some evidence on the uniqueness of bank loans. Journal of financial economics, Vol. 19 No. 2, pp.217-235. https://doi.org/10.1016/0304-405X(87)90003-1

James, C., (1992). Relationship-specific assets and the pricing of underwriter services. Journal of Finance, Vol. 47, pp.1865-1885. https://doi.org/10.2307/2328999

Jenkinson, T., \& Jones, H. (2004). Bids and allocations in european IPO bookbuilding. The Journal of Finance, Vol. 59 No. 5, pp.2309-2338. https://doi.org/10.1111/j.1540-6261.2004.00700.x

Jenkinson, T., \& Jones, H. (2009). Ipo pricing and allocation: a survey of the views of institutional investors. Review of Financial Studies, Vol. 22 No.4, pp.1477-1504. https://dx.doi.org/hhn079

Jenkinson, T., \& Ljungqvist, A. (2001). Going public: The theory and evidence on how companies raise equity finance. Oxford University Press on Demand.

Klein, P. G., \& Zoeller, K. (2001). Universal-bank underwriting and conflicts of interest: Evidence from german initial public offerings. Unpublished working paper, University of Georgia.

Krigman, L., Shaw, W. H., \& Womack, K. L. (1999). The persistence of IPO mispricing and the predictive power of flipping. The Journal of Finance, Vol. 54 No. 3, pp.1015-1044. https://doi.org/10.1111/0022-1082.00135

Krigman, L., Shaw, W. H., \& Womack, K. L. (2001). Why Do Firms Switch Underwriters? Journal of Financial Economics, Vol. 60 No. 2, pp.245-284. https://doi.org/10.1016/S0304-405X(01)00045-9

Kroszner, R. S., \& Rajan, R. G. (1994). Is the Glass-Steagall Act justified? A study of the US experience with universal banking before 1933. The American Economic Review, pp.810-832. https://www.jstor.org/stable/2118032

Ljungqvist, A. P., \& Wilhelm, W. J. (2002). Ipo allocations: Discriminatory or discretionary? Journal of Financial Economics, Vol. 65 No. 2, pp.167-201. https://doi.org/10.1016/S0304-405X(02)00138-1

Logue, D. E. (1973). On the pricing of unseasoned equity issues: 1965-1969. Journal of Financial and Quantitative Analysis, Vol. 8 No.1, pp.91-103. https://doi.org/10.2307/2329751

Loughran, T., \& Ritter, J. R. (2002). Why don't issuers get upset about leaving money on the table in IPOs? Review of financial studies, Vol. 15 No.2, pp.413-444. https://doi.org/10.1093/rfs/15.2.413

Lowry, M., \& Schwert, G. W. (2004). Is the IPO pricing process efficient? Journal of Financial Economics, Vol. 71 No.1, pp.3-26. https://doi.org/10.1016/j.jfineco.2006.05.006

Lowry, M., Officer, M. S., \& Schwert, G. W. (2010). The variability of IPO initial returns. The Journal of Finance, 65(2), pp.425-465. https://doi.org/10.1111/j.1540-6261.2009.01540.x

Lowry, M., Michaely, R., Volkova, E., et al. (2017). Initial public offerings: A synthesis of the literature and directions for future research. Foundations and Trends in Finance, Vol. 11 No.3, pp.154-320. https://doi.org/10.1561/0500000050

McCarthy, E. (1999). Pricing IPOs: Science or science fiction? Journal of Accountancy, Vol. 188 No.3, pp.51-58.

Michaely, R., \& Womack, K. L. (1999). Conflict of Interest and the Credibility of Underwriter Analyst Recommendations. Review of Financial Studies, Vol. 12 No.4, pp.653-686. https://doi.org/10.1093/rfs/12.4.653

Miller, T. W. (2018). Terminal values for firms with growth opportunities: explaining valuation and IPO price behavior. Studies in Economics and Finance, Vol. 35 No.2, pp.244-272. https://doi.org/10.1108/SEF-03-2016-0078

Morton, A. D. (1998). Factors and the pricing of IPO aftermarket returns. Studies in Economics and Finance, Vol. 19 No.1, pp.77-102. https://doi.org/10.1108/eb028748

Nimalendran, M., Ritter, J. R., \& Zhang, D. (2007). Do today's trades affect tomorrow's IPO allocations? Journal of Financial Economics, Vol. 84 No.1, pp.87-109. https://doi.org/10.1016/j.jfineco.2006.01.007

Petersen, M. A., \& Rajan, R. G. (1994). The benefits of lending relationships: Evidence from small business data. The Journal of finance, Vol. 49 No.1, pp.3-37. https://doi.org/10.2307/2329133

Petersen, M. A., \& Rajan, R. G. (1995). The effect of credit market competition on lending relationships. The Quarterly Journal of Economics, Vol. 110 No.2, pp.407-443. https://doi.org/10.2307/2118445 
Pichler, P., \& Wilhelm, W. (2001). A theory of the syndicate: Form follows function. The Journal of Finance, Vol. 56 No. 6, pp.2237-2264. https://doi.org/10.1111/0022-1082.00404

Pollock, T. G. (2004). The benefits and costs of underwriters' social capital in the us initial public offerings market. Strategic Organization, Vol. 2 No. 4, pp.357-388. https://doi.org/10.1177/1476127004047618

Puri, M. (1999). Commercial banks as underwriters: implications for the going public process. Journal of Financial Economics, Vol. 54 No. 2, pp.133-163. https://doi.org/10.1016/S0304-405X(99)00034-3

Reuter, J. (2006). Are IPO allocations for sale? evidence from mutual funds. The Journal of Finance, Vol. 61 No.5, pp.2289-2324. https://doi.org/10.1111/j.1540-6261.2006.01058.x

Ritter, J. R. (2011). Equilibrium in the initial public offerings market. Annu. Rev. Financ. Econ., Vol.3 No.1, pp.347-374. https://doi.org/10.1146/annurev-financial-102710-144845

Ritter, J. R., \& Welch, I. (2002). A review of IPO activity, pricing, and allocations. The Journal of Finance, Vol. 57 No.4, pp.1795-1828. https://doi.org/10.1111/1540-6261.00478

Ritter, J. R., \& Zhang, D. (2007). Affiliated mutual funds and the allocation of initial public offerings. Journal of Financial Economics, Vol. 86 No. 2, pp.337-368. https://doi.org/10.1016/j.jfineco.2006.08.005

Rumokoy, L. J., Neupane, S., Chung, R. Y., \& Vithanage, K. (2019). Underwriter network structure and political connections in the chinese IPO market. Pacific-Basin Finance Journal. Vol. 54, pp.199-214. https://doi.org/10.1016/j.pacfin.2017.10.005

Schenone, C. (2004). The effect of banking relationships on the firm's IPO underpricing. The Journal of Finance, Vol. 59 No. 6, pp.2903-2958. https://doi.org/10.1111/j.1540-6261.2004.00720.x

Sherman, A. E. (2005). Global trends in IPO methods: Book building versus auctions with endogenous entry. Journal of Financial Economics, Vol. 78 No.3, pp. 615-649. https://doi.org/10.1016/j.jfineco.2004.09.005

Sherman, A. E., \& Titman, S. (2002). Building the IPO order book: underpricing and participation limits with costly information. Journal of Financial economics, Vol. 65 No. 1, pp.3-29. https://doi.org/10.1016/S0304-405X(02)00133-2

Smith Jr, C. W. (1986). Investment banking and the capital acquisition process. Journal of Financial Economics, Vol. 15 No.1, pp. 3-29. https://doi.org/10.1016/0304-405X(86)90048-6

Spatt, C., \& Srivastava, S. (1991). Preplay communication, participation restrictions, and efficiency in initial public offerings. The Review of Financial Studies, Vol. 4 No. 4, pp.709-726. https://doi.org/10.1093/rfs/4.4.709

Stiglitz, J., \& Weiss, A. (1983). Alternative approaches to analysing markets with asymmetric information: reply. The American Economic Review, Vol. 73 No. 1, pp. 246-249. https://doi.org/10.7916/D8ZK5SNH

Thompson, T. H. (2016). Underpricing, partial price adjustments, and equity carve-outs. Journal of Economics and Finance, Vol. 40 No.2, pp.345-366. https://doi.org/10.1007/s12197-014-9311-5

Thornton, B., Adams, M., \& Hall, G. (2009). Do underwriters create value in the determination of the IPO final offering price? Journal of Applied Business Research, Vol. 25 No. 6, pp.1-12 https://doi.org/10.19030/jabr.v25i6.990

Varshney, S., \& Robinson, R. (2004). IPO research symposium review. Journal of Economics and Finance, Vol. 28 No. 1, pp.56-67. https://doi.org/10.1007/BF02761455

Wang, W., \& Yung, C., (2011) 'IPO information aggregation and underwriter quality', Review of Finance, Vol. 15 No. 2, pp.301-25. https://doi.org/10.1093/rof/rfp021

Wilhelm, W. J. (2005). Bookbuilding, auctions, and the future of the IPO process. Journal of Applied Corporate Finance, Vol. 17 No.1, pp.55-66. https://doi.org/10.1111/j.1745-6622.2005.024_1.x

\section{Notes}

Note 1. Usually, the first reported holding by institutional investors at the end of the offering quarter is used as a proxy for their participation in the IPO (Reuter, 2006; Ritter and Zhang, 2007; Field and Lowry, 2009; Goyal and Tam, 2013).

Note 2. In this paper, the terms 'underwriter' and 'investment bank' will be used interchangeably. 
Note 3. The midpoint of the initial price range usually represents the expected offer price (Hanley, 1993).

Note 4. The SEC guidelines provide a 'safe harbor' for listing firms who limit their price range to a designated percentage that has changed over time. Until September 2001 the SEC suggested a bona fide estimate for a price range greater than $\$ 2$ or $10 \%$ of the lower price; this indication was then relaxed in the volatile post-September 2001 period to greater than $\$ 2$ or $20 \%$ of the lower price (Jenkinson et al., 2006). However, the SEC has also asserted that a bona fide estimate for the price range should be no more than $\$ 2$ or $20 \%$ of the high end of the range.

Note 5. In most cases, these studies use samples of European offerings because data on both allocation and underwriters' order books is difficult to obtain, especially for the U.S. market (Lowry et al. 2017).

\section{Copyrights}

Copyright for this article is retained by the author(s), with first publication rights granted to the journal.

This is an open-access article distributed under the terms and conditions of the Creative Commons Attribution license (http://creativecommons.org/licenses/by/4.0/). 